\title{
Rural Tourism as Risk Factor for the Transmission of Schistosomiasis in Minas Gerais, Brazil
}

\section{Martin J Enk, Roberta L Caldeira*, 0 mar S Carvalho*, Virginia T Schall/ ${ }^{+}$}

\author{
Laboratório de Educação em Saúde *Laboratório de Helmintoses Intestinais, Centro de Pesquisas René Rachou-Fiocruz, \\ Av. Augusto de Lima 1715, 30190-002 Belo Horizonte, MG, Brasil
}

\begin{abstract}
Recently, the booming rural tourism in endemic areas of the state of Minas Gerais was identified as a contributing factor in the dissemination of the infection with Schistosoma mansoni. This article presents data from six holiday resorts in a rural district approximately $100 \mathrm{~km}$ distant from Belo Horizonte, MG, Brazil, where a possibly new and until now unperceived way of transmission was observed. The infection takes place in swimming pools and little ponds, which are offered to tourists and the local population for fishing and leisure activities. The health authorities of the district reported cases of schistosomiasis among the local population after visiting these sites. As individuals of the non-immune middle class parts of the society of big urban centers also frequent these resorts, infection of these persons cannot be excluded. A malacological survey revealed the presence of molluscs of the species Biomphalaria glabrata and Biomphalaria straminea at the resorts. The snails (B. glabrata) of one resort tested positive for $\mathrm{S}$. mansoni. In order to resolve this complex problem a multidisciplinary approach including health education, sanitation measures, assistance to the local health services, and evolvement of the local political authorities, the local community, the tourism association, and the owners of the leisure resorts is necessary. This evidence emphasizes the urgent need for a participative strategic plan to develop the local tourism in an organized and well-administered way. Only so this important source of income for the region can be ensured on the long term without disseminating the disease and putting the health of the visitors at risk.
\end{abstract}

Key words: Schistosoma mansoni - schistosomiasis - rural tourism - control - sanitation - Belo Horizonte Minas Gerais - Brazil

The booming rural tourism to and within endemic areas is identified as a contributing factor in the dissemination of the infection with Schistosoma mansoni. In two localities, both within the metropolitan area of Belo Horizonte, Minas Gerais, Brazil, we have observed a silent and until now unperceived way of transmission. The transmission takes place in swimming pools and little ponds, which are offered to tourists for fishing and other leisure activities at these resorts. The first investigation, the occurrence of 17 cases of acute schistosomiasis in the metropolitan area of Belo Horizonte was described elsewhere (Enk et al. 2003). There was shown that a fraction of the population with no acquired immunity from metropolitan, non-endemic areas became exposed to the disease. This fraction consists mainly of individuals from the non-immune middle class parts of the society in urban centers.

Similar occurrences were described in two tourist areas in Pernambuco by Barbosa et al. (2000, 2001).

In the current study in Minas Gerais, six holiday resorts were visited in a district located approximately 100 $\mathrm{km}$ in the northeast from Belo Horizonte. The area has been known as endemic for schistosomiasis for decades

Financial support: CNPq, Fapemig

${ }^{+}$Corresponding author. Fax: +55-31-329.53115. E-mail: vtschall@cpqrr.fiocruz.br

Received 28 May 2004

Accepted 26 July 2004 and intermediate hosts of the species Biomphalaria glabrata were identified in the 1950s (Pinto \& Deslandes 1953 ) and B. straminea in the 1970s (Katz et al. 1970). Because of the natural beauty of the region and the growing weekend tourism, owners of sites in the area started successively to transform their agricultural activities into tourism and leisure orientated services, having better income in mind. Besides restaurant and sometimes boarding facilities these resorts offer natural swimming pools and "fish and pay" for leisure activities to the local population and tourists. In some of them, general sanitation facilities such as bathrooms are rare, in bad conditions or out of hand. Sewage systems at the resorts are not existent or precarious, which clearly facilitates the propagation of the disease. The health authorities of the district reported cases of schistosomiasis among the local population after visiting these sites. Besides this, recent preliminary parasitological examinations of the permanent residents of the area confirmed a prevalence of $24.38 \%$ (Massara, pers. commun. 2004). This indicates clearly that the local population is maintaining the cycle of infection.

\section{MATERIALS AND METHODS}

Sites - The six sites investigated are located approximately $100 \mathrm{~km}$ to the northeast of Belo Horizonte, Minas Gerais, Brazil. Each of the sites is close to a brook, which serves as water source for natural swimming pools, little ponds or fish reservoirs. (Fig. 1). Tourist of the local area, the surrounding cities, and Belo Horizonte, frequent the sites for leisure purposes especially during weekends.

In Table I all resorts visited are categorized according to the offered leisure activities. 
Malacological survey - A team of the Centro de Pesquisas René Rachou visited the sites in 2003. The purpose of these visits was to identify and explore possible sources of infection and to collect snails. During the field trip snails were collected from little ponds, brooks crossing the resorts, fish reservoirs, natural swimming pools, and natural showers. Snail collection was performed with perforated metal dippers fixed on a wooden stick

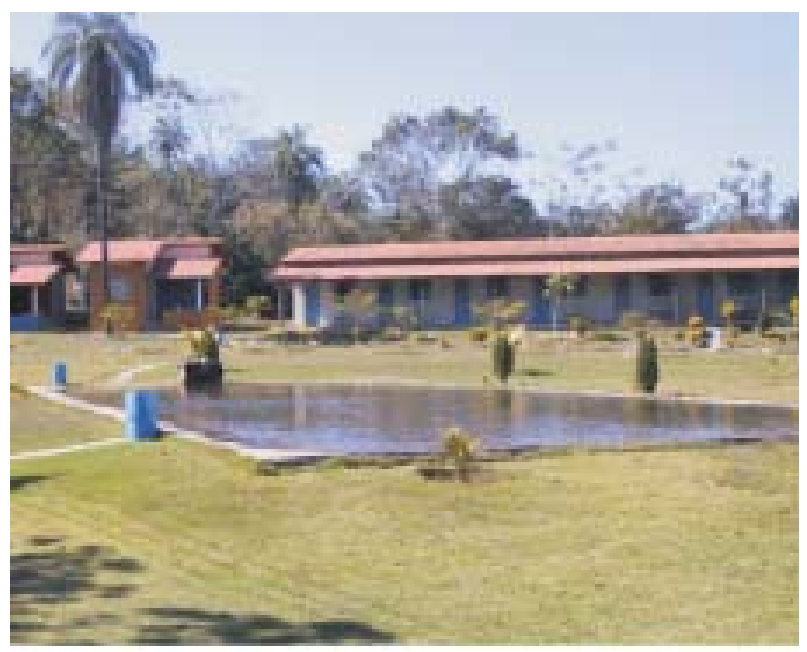

Fig. 1: a typical holiday resort for the area studied (northeast of Belo Horizonte, Minas Gerais, Brazil)

TABLE I

Leisure activities offered at six sites in an area approximately $100 \mathrm{~km}$ northeast of Belo Horizonte, Minas Gerais

\begin{tabular}{lcccc}
\hline Location & $\begin{array}{c}\text { Natural } \\
\text { swimming pool }\end{array}$ & $\begin{array}{c}\text { Fish } \\
\text { and pay }\end{array}$ & $\begin{array}{c}\text { Restaurant } \\
\text { facilities }\end{array}$ & Boarding \\
\hline Site 1 & + & + & + & - \\
Site 2 & + & + & + & + \\
Site 3 & + & - & + & - \\
Site 4 & + & - & + & - \\
Site 5 & + & - & + & - \\
Site 6 & - & + & + & - \\
\hline
\end{tabular}

+ available at the site, - not available at the site

TABLE II

Malacological survey at six sites offering leisure activities in an area approximately $100 \mathrm{~km}$ northeast of Belo Horizonte, Minas Gerais, Brazil

\begin{tabular}{llrcl}
\hline & & \multicolumn{3}{c}{ Snails } \\
\cline { 3 - 5 } Location & Mollusc species & Examined & Positives & $\%$ \\
\hline Site 1 & B. straminea & 15 & 0 & 0 \\
Site 2 & B. straminea & 238 & 0 & 0 \\
Site 2 & B. glabrata & 3 & 0 & 0 \\
Site 3 & B. straminea & 45 & 0 & 0 \\
Site 4 & B. glabrata & 55 & 0 & 0 \\
Site 5 & B. glabrata & 88 & 6 & 6.8 \\
Site 6 & non & 0 & 0 & 0
\end{tabular}

B.: Biomphalaria
(Thiengo 1995). Wooden tweezers were also used for the collection procedure.

Snails - After collection, the snails were taken to the laboratory where those alive were measured and examined under artificial light for Schistosoma mansoni cercariae. Ten were put for morphological identification and molecular analysis, and the others submitted to squeezing between glass plates for detecting presence of sporocists and cercariae.

Morphological identification of snail populations The specimens were killed, a fragment from the cephalopodal region of each removed for subsequent DNA extraction and the body was fixed (Deslandes 1951). After fixation each specimen was identified based on comparative morphology of the reproductive organs and shell as described by Deslandes (1951) and Paraense (1975).

Molecular analysis - DNA extraction was performed, using the Wizard Genomic DNA Purification Kit (Promega), modified by Vidigal et al. (2000). The entire ITS region was amplified using the primers ETTS2 (5-TAAC AAGG TTTCCGTAGGTGAA-3) and ETTS1 (5-TGCTTAAGTT CAGCGGGT-3) (Kane \& Rollinson 1994). Polymerase chain reaction amplification and restriction fragment length polymorphism (PCR-RFLP) conditions were the same described by Vidigal et al. (1998), with DdeI enzyme.

\section{RESULTS}

Malacological survey - Out of a total number of 753 (309 dead and 444 alive) snails collected in the area, the 444 molluscs alive were submitted to identification (146 B. glabrata and 298 B. straminea). The results from PCRRFLP confirmed the morphological identification. The 444 snails alive were examined for infection with $S$. mansoni. A summary of the malacological survey is given in Table II. Non of the molluscs of the species B. straminea were found infected with $S$. mansoni. A number of six snails of the species B. glabrata showed to be positive for $S$. mansoni cercariae. All six positive molluscs were obtained at site 5, from the natural swimming pool (Fig. 2) and from the attached natural shower (Fig. 3). Consequently $6.81 \%$ of the examined snails from site 5 were infected.

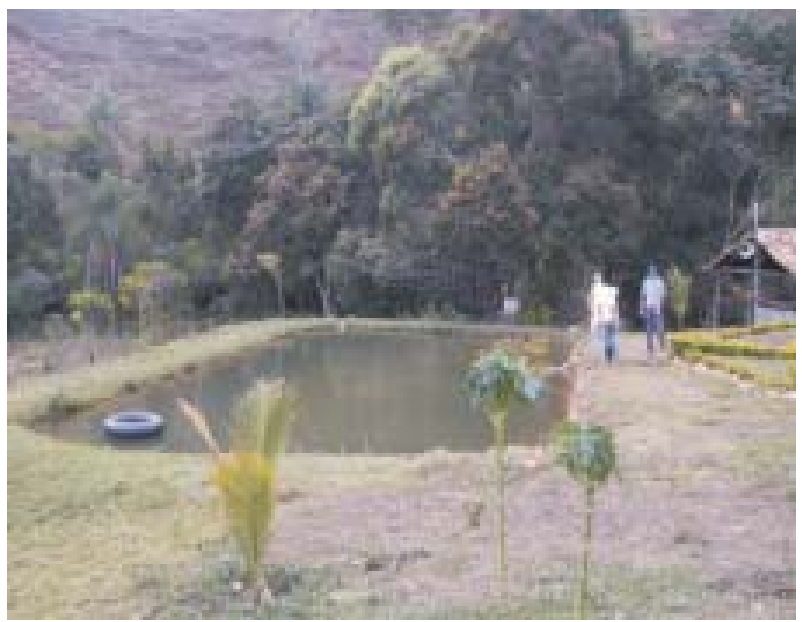

Fig. 2: natural swimming pool at site 5 where Biomphalaria glabrata infected with Schistosoma mansoni were found. 


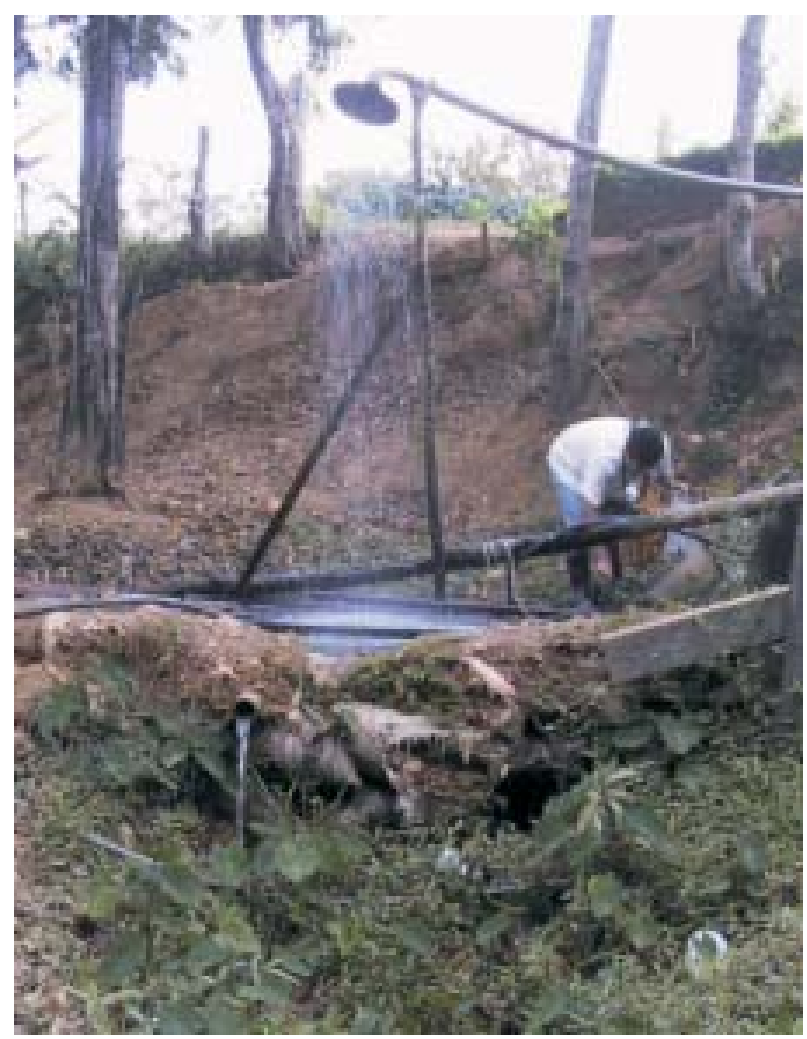

Fig. 3: natural shower at site 5 where Biomphalaria glabrata infected with Schistosoma mansoni were found.

\section{DISCUSSION}

It is worth to note here that, although infected snails have been found only at site 5 , transmission of schistosomiasis at the other sites cannot be excluded. The simple presence of susceptible snails in an endemic area with a high concentration of people - in this case local and regional tourists - having water contact due to their leisure activities gives enough reason to assume that transmission at the other sites may take place as well.

Rural tourism as well as ecological and adventure tourism is a recently growing new facet in the ways of transmission and dissemination of schistosomiasis and a new challenge to the control of the disease. The natural environment, which is highly appreciated by the tourists, often coincidentally represents the ideal habitat for the intermediate host. The combination with poor sanitation at the resorts in endemic areas increases significantly the probability that the disease is established and transmission and dissemination takes place. The poor sanitation infrastructure is only one result of the uncontrolled and informal growing of tourism in this and similar areas. Longterm negative socio-demografic and environmental consequences including the dissemination of diseases can be expected because of this spontaneous and amateurlike exploration of rural tourism in order to please the visitors and increase the income (Moura et al. 2003).

This complex issue, which involves the health of tourists, the dissemination of the disease, financial interests and the planning and development of the tourism infra- structure, needs a multidisciplinary approach to find a viable solution. Nothing will be achieved if the health authorities simply close affected resorts. Therefore a process of creating awareness and critical consciousness about the problem among all parties concerned must be initiated to see - according to Freire (1992) - "the problem behind the problem". In our specific case there are perspectives to establish cooperation between the owners of the holiday resorts, the local health authorities, and specialists of different scientific and technical areas. The objective is to elaborate a package including health education, sanitation measures, assistance to the local health services and evolvement of the local political authorities, the local community, and the owners of the leisure resorts to find an individual solution for each site. Additionally an education campaign about schistosomiasis for the local population and health as well as political authorities was carried out to increase attention to this problem. Finding sustainable and viable solutions to resolve this particular health problem of the holiday resorts certainly will serve as an example and encourage other developments in the district such as establish mechanisms of schistosomiasis control and strategic planning for rural tourism.

Having in mind the high number of persons positive for schistosomiasis and consequently elevated numbers of persons at risk in the state of Minas Gerais (Katz \& Peixoto 2000), the above mentioned initiatives have to be transformed into public state policies. In this way preservation of the environment and improvements in health will be promoted by ensuring economic stability on a large scale and sustainable basis and not only punctual and restricted to limited areas in consequence of scientific investigations.

\section{ACKNOWLEDGEMENTS}

To José Geraldo Amorim da Silva for the capture of the molluscs; to Cristiano L Massara and Heliton Barros for their valuable contributions during the field work.

\section{REFERENCES}

Barbosa CS, Pieri OS, Silva CB, Barbosa FS 2000. Ecoepidemiologia da esquistossomose urbana na ilha de Itamaracá, Pernambuco. Rev Saúde Pública 34: 337-341.

Barbosa CS, Montenegro SML, Abat FG, Domingues AL 2001. Specific situations related to acute schistosomiasis in Pernambuco, Brasil. Mem Inst Oswaldo Cruz 96 (Suppl. 5): $169-172$.

Deslandes N 1951. Técnica de dissecação e exame de planorbídeos. Rev Serv Espec Saúde Pública 4: 371-382.

Enk M, Amorim A, Schall VT 2003. Acute schistosomiasis outbreak in the metropolitan area of Belo Horizonte, Minas Gerais: alert about the risk of unnoticed transmission incresead by growing ruaral tourism. Mem Inst Oswaldo Cruz 98 (Suppl. 6): 745-750.

Freire P 1992. Pedagogia da Esperança: Um Reencontro com a Pedagogia do Oprimido, Paz e Terra, Rio de Janeiro, 245 pp.

Kane RA, Rollinson D 1994. Repetitive sequences in the ribosomal DNA internal transcribed spacer of Schistosoma haematobium, S. intercalatum, and S. mattheei. Mol Biochem Parasitol 63: 153-156.

Katz N, Peixoto SV 2000. Análise crítica da estimativa do número de portadores de esquistossomose mansoni no Brasil. Rev 
Soc Bras Med Trop 33: 303-308.

Katz N, Antunes CMF, Andrade RM, Pellegrino J, Coelho PMZ 1970. An attempt to control schistosomiasis mansoni in an endemic area by combining clinical treatment and molluscicide application. J Parasitol 56: 434.

Moura AMF, Ribeiro BMG, Oliveira MBS, Archanjo ALC 2003. Povoado da Lapinha, Santana do Riacho, Minas Gerais: planejamento, ordenamento e gestão do ecoturismo. Rev de Iniciação Cientifica Newton Paiva 2001/2002: 313-336.

Paraense WL 1975. Estado atual da sistemática dos planorbídeos brasileiros. Arq Museu Nacional do Rio de Janeiro 55: 105128.

Pinto DB, Deslandes N 1953. Contribuição ao estudo da sistemática de planorbídeos brasileiros. Rev Ser Espec Saúde
Pública 6: 135-167.

Thiengo S 1995. Técnicas malacológicas. In FS Barbosa, Tópicos em Malacologia Médica, Fiocruz, Rio de Janeiro, p. 225260.

Vidigal THDA, Caldeira RL, Simpson AJG, Carvalho OS 2000. Further studies on the molecular systematics of Biomphalaria snails from Brazil. Mem Inst Oswaldo Cruz 95: 57-66.

Vidigal THDA, Spatz L, Nunes DN, Simpson, AJG, Carvalho OS, Dias Neto E 1998. Biomphalaria ssp. identification of the intermediate sanil hosts of Schistosoma mansoni by polymerase chain reaction amplification and restriction enzyme digestion of the ribosomal RNA gene intergenic spacer. Exp Parasitol 89: 180-187. 